\title{
COMMENT
}

\section{Comment on "Crustal faults in the Chilean Andes: geological constraints and seismic potential" by Santibáñez et al. (2019), Andean Geology 46 (1): 32-65}

\author{
Gregory P. De Pascale ${ }^{1}$ \\ 'Departamento de Geología, Facultad de Ciencias Físicas y Matemáticas (FCFM), Universidad de Chile, Plaza Ercilla 803, Santiago. \\ snowyknight@gmail.com
}

Understanding the location and nature of Quaternary active crustal faults is critical to reduce both the impact of fault rupture and strong ground motions hazards (when these faults rupture causing earthquakes). It is also important for understanding how and where deformation related to plate tectonics is accommodated along geological structures (oftentimes faults and folds). In Chile, work on active tectonics in the upper crust (neotectonics or earthquake geology) is relatively new, in particular regarding fault-focused studies. Therefore, any effort to further progress in our understanding of active fault systems for the benefit of the public, and for aiding local and regional governments and the earthquake engineering and scientific community with mitigation strategies should be applauded. Demonstrating where active faults are located through careful mapping, and to determine how fast they accommodate tectonic deformation and their seismic and fault rupture hazards are key questions in neotectonics. Recently Santibáñez et al. (2019) explore active fault systems in the Chilean Andes. In their paper they outline active and potentially seismogenic (i.e., earthquake producing) fault systems in the Chilean Andes through a review of the literature, seismicity, case studies (earthquakes), and modeling data and then they define potential tectonic domains for subdivision of Chile. These domains were suggested to allow "a first-order approach for seismic potential assessment" (Santibáñez et al., 2019). The three subdivisions they suggest, i.e., domains are the External Forearc, Inner Forearc and Volcanic Arc, were proposed based on several fault parameters (e.g., fault length), case studies, the morphotectonic setting and seismicity. Their paper generates a great foundation to build upon for both the active tectonics and geological hazards community, in addition to being useful for potential end users such as the Chilean local and national government from a planning perspective. Although the Santibáñez et al. (2019) paper takes steps in the right direction, and should be considered an important contribution to the scientific community, this comment addresses three potential issues with their analysis and conclusions that should be reflected upon by the seismic hazard and active tectonics community. These ideas are summarized below and expanded on in detail thereafter.

Specifically three main concerns (i.e., points) with the Santibáñez et al. (2019) assessment of Crustal Faults in the Chilean Andes are: 1) They mention that crustal faults "are known to produce earthquakes with a maximum of moment magnitude (Mw) of 7.0 to 7.5 " and do not provide a detailed review of the importance of ground accelerations versus type of earthquake (i.e., subduction zone versus crustal and the importance of locality/proximity of smallermagnitude events). Additionally, although Ms is not equal to $\mathrm{Mw}$, crustal earthquakes from the rupture of crustal faults of up to Ms 7.8 and Mw 7.7 were recorded in Chile, and globally with events $\geq \mathrm{Mw}$ 8.0. 2) There appears that of the value of geological and paleoseismological data to evaluate active faults receives less weight in favor of modeling, seismological, or geophysical observations. In Japan, 
California, and New Zealand (the world leaders on this topic), these field data and seismologic observations are used to design and evaluate quality of any and all models that are developed to explore seismic hazard and fault behaviour. 3) The division of Chile into 3 tectonic domains ignores the distinct strike-slip setting (or domain) of the southern portion of South America, i.e., Magallanes and Tierra Del Fuego, and the proposed extensional setting with normal faulting to the east of the strike slip Plate Boundary there. Additionally, analysis of seismicity alone could severely underestimate the potential maximum magnitudes that these faults are capable of in Chile (where they exist) based on global seismicity and earthquake geology data.

Regarding point 1, Santibáñez et al. (2019) mention that crustal faults "are known to produce earthquakes with a maximum of moment magnitude $(\mathrm{Mw})$ of 7.0 to $7.5 \%$. This is factually incorrect not only in Chile but globally, with maximum values too low, and misleading from a seismic hazard perspective (i.e., there are recorded earthquakes in the global historical seismic catalogues with events that are up to at least Ms 7.8 (noting that Ms is not equal to $\mathrm{Mw}$ ) and $\mathrm{Mw} 7.7$ in Chile: e.g., Lomnitz, 1970; Perucca et al., 2016). In their paper, Santibáñez et al. (2019), state that "crustal faults within the overriding South American Plate (intraplate crustal faults/ earthquakes are hereafter named simply "crustal" faults/earthquakes)". This definition of crustal faults is only partially correct, in my opinion, as some interplate faults (i.e., faults that occur at the boundary between two tectonic plates) are also upper plate crustal faults. For example the San Andreas Fault System in California, or the Magallanes Fault System in Chile and Argentina, are interplate populations of strike slip faults (i.e., they are both plate boundary faults) that also happen to be crustal faults because they occur in the upper crust. One could argue that plate boundary faults have a larger seismic potential than other crustal faults based on famous examples like the San Andreas, however analysis of global crustal reverse faults demonstrates that reverse faults oftentimes have magnitudes exceeding those of the largest known strike slip faults (e.g., Lettis et al., 1997). A perhaps better division of faults as seismic sources in Chile is therefore binary: A) subduction zone faults which are subcrustal (like the megathrust located along the subduction zone between the Nazca and South American Plates), and B) crustal faults which include strike slip plate boundary (i.e., interplate) faults. This for example is how New Zealand differentiates fault sources for the National Seismic Hazard model of New Zealand (Stirling et al., 2012), i.e., subduction zone earthquakes and crustal earthquakes (from 0-30 km depth). Thus fault sources should be considered binary from the aspect of earthquake effects as well based on shaking intensity. Crustal faults and the earthquakes they generate are located, by definition in the upper crust and because this is close to where we live, on the Earth's surface, these events thus generate higher intensities. As an immigrant to Chile, I am constantly reminded by the public that magnitude 6 earthquakes are "small" (which are oftentimes along the megathrust plate boundary), but the characterisation of earthquakes by the energy released (e.g., Richter scale) is only part of the story. I experienced a small, local, magnitude 6.2 earthquake in Christchurch, New Zealand in 2011 and saw the extreme $\$ 30$ Billion New Zealand Dollar damage that this "small" event created (e.g., Kaiser et al., 2012). Although this was a "small" earthquake in terms of total energy released, because it was shallow $(<5 \mathrm{~km})$ and local (within the City of Christchurch), the intensity of the shaking and outcomes of this shaking on the built and natural environment was quite extreme. Intensity is most commonly characterised using the Mercalli scale (or Modified Mercalli Intensity-MMI) which can be directly related to the peak ground acceleration (PGA). This event had PGA's (vertical) close to $2.2 \mathrm{~g}$ and a Mercalli intensity of 11 out of 12 (Kaiser et al., 2012; Stirling et al., 2015). The intensity, as measured by PGA is the key differential here. Great to giant megathrust earthquakes in Chile are very important, they generate Pacific Ocean wide tsunami and have major impact on the coastline and history of Chile, but they occur farther away from us and thus the seismic waves have longer to attenuate and disperse. This means megathrust earthquake have less accelerations when they reach the Earth's surface. For example, during the Mw 8.32015 Illapel Earthquake in central Chile, maximum PGA's of $0.83 \mathrm{~g}$ were recorded at one station while most stations had recorded PGA's of less than $0.2 \mathrm{~g}$ (Candia et al., 2017). Santibáñez et al. (2019) do carefully outline a number of case studies, that have estimates of PGA values associated with them from crustal events, that also outlines these stark differences between megathrust events and crustal events regarding intensity. 
Thus in summary, I believe that crustal faults in Chile should be a simple division between A) the megathrust events along the three subduction zones from North to South, Nazca-South American Plates, the Antarctica-South American Plates, and the Antarctica-Scotia Plate, and B) crustal faults found in the overlying South American and Scotia Plates that reach (i.e., rupture to) the surface or very near surface (i.e., blind faults).

In terms of the magnitude ranges mentioned by Santibáñez et al. (2019), as mentioned above these are perhaps inconsistent with the literature and underacknowledge magnitude possibilities from global fault systems that we should consider as possibilities for similar fault systems in Chile. Specifically in 1949, a Ms 7.8 and Ms 7.5 crustal earthquakes occurred in Tierra del Fuego which were related to the strike-slip crustal faults associated with the plate boundary Magallanes Fault System (e.g., Forsyth and Uyeda, 1975; Winslow, 1982; Jaschek et al., 1982; Pedrera et al., 2014; Sandoval and De Pascale, 2020; Roy et al., 2020). Additionally, new research by Kanamori and Rivera (2017) along the master fault of the Liquine-Ofqui fault zone (LOFZ), suggest that an Mw 7.7 aftershock of the $1960 \mathrm{Mw} 9.5$ giant Valdivia earthquake occurred on June 6, 1960 as a dextral strike-slip event along the LOFZ. The 2007 Aysen earthquake sequence led Kanamori and Rivera (2017) and Kanamori et al. (2019) to conclude that a north-south trending right-lateral strike-slip structure, likely the LOFZ is responsible for this June $6 \mathrm{Mw} 7.7$ event, and that the best match for the observed waveforms from this event is $11 \mathrm{~km}$ (i.e., in the crust), although they mentioned that the June $6^{\text {th }}$ event could be considerably deeper than $11 \mathrm{~km}$. Although this could be a slow earthquake, and perhaps from near the base of the brittle-ductile transition zone, it should still be considered within the realm of observations and potentialities along crustal faults in Chile. Importantly, Kanamori and Rivera (2017) state that they are unaware of any crustal fault evidence along the LOFZ, however recent work by Vargas et al., (2013) and work by Villalobos et al. (2020), clearly demonstrate presence of active crustal faults associated with the LOFZ, and coincident with the Kanamori and Rivera (2017) data with associated evidence for prehistoric fault ruptures. Noting the short timing of the global recorded seismic network, the geologic record forms the only prehistoric registry of major earthquakes in Chile. Furthermore, just because
Ms 7.8 is the maximum recorded event in Chile for a crustal earthquake, does not mean that even larger events are not possible. Global evidence shows that all three styles of faulting mentioned in Santibáñez et al. (2019) are capable of reaching higher than the values listed in their paper, with normal faults (up to Mw 7.6; Middleton et al., 2015), reverse faults ( $\geq \mathrm{Mw} 8$ ), and strike-slip fault ( $\geq \mathrm{Mw} 8.0$ and up to Mw 8.6; e.g., Satriano et al., 2012; De Pascale and Langridge, 2012). Why would faults found in Chile behave differently, if of course these active structures have sufficient fault area within the seismogenic zone, which admittedly is not always known? Estimations for seismic potential from global evidence shows, normal fault earthquakes, although generally from Mw 7.0 to 7.3 (Schwartz and Coppersmith, 1984), can extend up to Mw 7.6 (Middleton et al., 2015), reverse faults earthquakes can be up to $\mathrm{Mw} 8.3$ (e.g., Lettis et al., 1997), and strike-slip fault earthquakes $\geq \mathrm{Mw} 8.0$ and up to Mw 8.6 (e.g., Satriano et al., 2012; De Pascale and Langridge, 2012). Thus the potential estimates ("Volcanic domain" Mw 6.2 to 6.7; "Outer Forearc" Mw 7.0 to 7.5 and "Inner Forearc" Mw 7.2) as suggested by Santibáñez et al. (2019) seem perhaps a bit low and perhaps a mention here about the possibilities for these faults, based on global data, will be better aligned with global practices. Under estimations of events magnitude and impacts and possibilities do occur (Table 1). The recent 2016 Mw 7.8 Kaikoura New Zealand Earthquake was an event that involved a number of smaller crustal faults that connected ruptures and linked up to make a larger event (e.g., Hamling et al., 2017). In this instance there is also some evidence that these faults may have also connected with the subduction interface (Hamling et al., 2017), which further complicates the simple binary crustal and subcrustal discussion above. If and when there is interplay between crustal faults and subcrustal faults, this discussion and the potential magnitudes associated with these complex ruptures of course becomes much larger. To conclude this section, it is my opinion that the magnitude ranges for crustal earthquakes suggested by Santibáñez et al. (2019) are on the low side and the ranges listed above are more consistent with global understanding of possibilities within crustal fault systems. At minimum in the "Volcanic domain" should have events up to at least Mw 7.7 as likely possible for intra-arc faults like the master fault in the LOFZ. 
TABLE 1. THREE MAJOR $21^{\text {ST }}$ CENTURY EARTHQUAKES (2004 INDIAN OCEAN, 2010 MAULE CHILE, AND 2011 TOHOKU JAPAN).

\begin{tabular}{|c|c|c|c|c|c|c|c|}
\hline $\begin{array}{l}\text { Historical } \\
\text { Earthquake }\end{array}$ & Year & $\begin{array}{c}\text { Expected } \\
\text { rupture } \\
\text { length }(\mathrm{km})\end{array}$ & $\begin{array}{l}\text { Rupture } \\
\text { length } \\
(\mathrm{Km})\end{array}$ & $\begin{array}{l}\text { Average and } \\
\text { max slip (m) }\end{array}$ & $\begin{array}{c}\text { Expected } \\
\text { magnitude } \\
(\mathrm{Mw})\end{array}$ & $\begin{array}{c}\text { Actual } \\
\text { Magnitude } \\
\text { (Mw) }\end{array}$ & Reference \\
\hline $\begin{array}{l}\text { Indian Ocean } \\
\text { Sumatra }\end{array}$ & 2004 & $<250$ & 1,500 & 7 and 20 & $<8$ & 9.1 to 9.3 & $\begin{array}{l}\text { Kagan et al., 2011; } \\
\text { Gupta and Ghalaut, } 2013\end{array}$ \\
\hline Maule, Chile & 2010 & $\sim 100$ & 700 & 10 average & 7.5 or $8-8.5(*)$ & 8.8 & $\begin{array}{l}\text { Nishenko, 1991; } \\
\text { *Ruegg et al., 2009; } \\
\text { Kagan et al., } 2011\end{array}$ \\
\hline Tohoku, Japan & 2011 & n.d. & 300 & $40 \max$ & 7.7 to 8.35 & 9.1 & Kagan and Jackson, 2013 \\
\hline \multicolumn{8}{|c|}{ Future earthquaques on faults without historic ruptures } \\
\hline $\begin{array}{l}\text { Alpine Fault, } \\
\text { New Zeland }\end{array}$ & n.a. & $>300$ & $?$ & $\begin{array}{c}\sim 7.5 \mathrm{~m} \\
\text { (expected) }\end{array}$ & 7.9 to 8.2 & $?$ & De Pascale et al., 2014 \\
\hline LOFZ, Chile & n.a. & $?$ & $?$ & $?$ & 7.1 & $?$ & Vargas et al., 2013 \\
\hline $\begin{array}{l}\text { San Ramón } \\
\text { Fault, Chile }\end{array}$ & n.a. & $15-35$ & $?$ & - & $\sim 7.5$ & $?$ & Vargas et al., 2014 \\
\hline
\end{tabular}

Three major $21^{\text {st }}$ Century earthquakes (2004 Indian Ocean, 2010 Maule Chile, and 2011 Tohoku Japan) where the expected fault displacements, rupture lengths, and magnitudes were all underestimated (as outlined by Kagan et al., 2013) prior to these events due to ruptures continuing past supposed fault rupture/segment boundaries. Of course these are subcrustal events from subduction zones, however these same underestimates could and have taken place along crustal faults. For example the $2016 \mathrm{Mw} 7.8$ Kaikoura New Zealand Earthquake (e.g., Hamling et al., 2017), was a complex rupture that connected a number of smaller crustal faults, each with their own seismic potential into one large 7.8 event. Note that the studies listed in the second section below (along faults without historic records of rupture, i.e., New Zealand's Alpine Fault, and Chile's Liquiñe-Ofqui fault zone (LOFZ), and San Ramón Fault) have a number of uncertainties (or data gaps), and based on the examples listed here may be underestimating effect (and thus seismic hazard). Note that n.a. is not applicable and n.d. is not determined. It is important for the seismic hazard and active tectonics community to acknowledge wider possibilities during future events based on these previous underestimates and based on evidence from historic events.

Also in regards to point two, by potentially understating the value of geological and paleoseismological data to evaluate active faults (Santibáñez et al., 2019 sections 3 and 6) perhaps in favor of modeling or geophysical observations (i.e., recorded seismicity) is a cause for reflection. It is well known that prior to recorded (written records) and seismic networks (which in Chile are very regional and covering a limited time-frame), the only way historic (that is post written records and pre seismic networks) and prehistoric earthquakes are recorded in the geologic record (i.e., paleoseismology or earthquake geology) and oral traditions. Depending on the tectonic environment of the fault and how fast it is slipping (i.e., slip rate), the interval (or recurrence) between large earthquakes range from decades to thousands of years (Sibson, 2002), thus modern instrumental data and observations document a small fraction of the observation time for any individual fault or region (Grant Ludwig, 2013). Tectonic geomorphology from remote sensing and field investigations are key to this end to obtain hard field data regarding motion along faults. Importantly, using microseismicity observations to generate a frequency-magnitude distribution (i.e., Gutenberg and Richter, 1956), from around active faults to characterise and estimate return time for major crustal fault ruptures and maximum magnitudes from associated earthquakes is known to be incorrect for at least 196 faults (e.g., Wesnousky, 1994; Wyss, 2020; and references within). Thus, providing less weight to the importance of geological and paleoseismic data is troublesome because low-frequency and potentially high impact (not always high magnitude) events happen over such long time scales that they are only recorded in the geologic record, i.e., not in the seismicity. For example, as mentioned above the Mw 6.3 Christchurch New Zealand earthquake in 2011 (e.g., Kaiser et al., 2012; Li et al., 2014). This was a low frequency, low magnitude (only Mw 6.3), high stress drop event, and high consequence event because of the shallow nature of the earthquake and 
location directly under the City of Christchurch, but without any prior historic event (in the short written history of New Zealand-since 1840). Understanding how often these Christchurch-style events occur can only be determined using earthquake geology and paleoseismic studies. Thus, geologic data and paleoseismic data are critical and fundamental to the formation and quality of any models produced to evaluate active fault systems. Models evaluating aspects of active faults produced without adequate or realistic inputs based on real field constraints, have limited to no value. Clearly, any seismic hazard evaluation must and should combine site and faultspecific field observations and fault characterisation (including all uncertainties) with modeling, but modeling without critical geological inputs that attempt to constrain geologic structures (faults and folds) may be of limited value and should be used with extreme caution. Nevertheless, Santibáñez et al. (2019), do an excellent job of outlining what is known about currently known geological structures and comparing them with historical events as recorded in the seismicity (oftentimes without any identified surface ruptures), and a combined geological data plus geodetic data plus seismic and other geophysical data is a sound approach for comprehensive evaluation of faults at a regional or national scale. Related to this, a national seismic hazard model (e.g., Stirling et al., 2012; New Zealand), had a "team of earthquake geologists, seismologists, and engineering seismologists... collectively produced an update of the national probabilistic seismic hazard model for New Zealand". These models have fault sources (e.g., in Chile the San Ramón fault), each with their own parameters outlined based on inputs (all with various uncertainties based on geologic characteristics derived from field and remote sensing work), which then leads to reliable modeling and model outcomes. Obviously when there are limited field data and existing resources or published literature, this becomes a challenge, however models that are developed about fault systems in Chile in the absence of field data should have clear uncertainties outlined for the users of these models. Hopefully moving forward, the Chilean research community can work together to build a better understanding of seismic hazard and neotectonics using solid field data combined with robust models to better constrain seismic and fault rupture hazards and associated coseismic geohazards such as landslides and liquefaction. A clear outcome of this would be a new Chilean National Seismic Hazard Model.

My second concern within point two, is there are some numbers and ideas regarding fault slip that are mentioned are also not completely correct and do not consider a comprehensive coverage of the literature nor global analogues that are helpful for us to gain insight from. This is important because if the academic community creates research that is then adopted by the private sector or government, and is not comprehensive, then it has a potential to mislead. For example in section 6.1 there is a mention "of maximum average displacement during earthquakes can generally reach up to $2 \mathrm{~m}$, or over 2 $m$ in extraordinary cases", whereas earlier in the paper in the section on the San Ramón Fault, they mention in section 5.2.2 that the reverse San Ramón Fault has displacements of $\sim 5 \mathrm{~m}$ (Vargas et al., 2014). The Magallanes Fault in southern Patagonia in both Chile and Argentina had reported single event strike-slip displacements of 4-6 m (Costa et al., 2006), with an average slip from the 1949 earthquake of $6 \pm 0.5 \mathrm{~m}$ based on displaced farm fences (Roy et al., 2020), which is consistent with single event slip during strike slip events globally (e.g., Wesnousky, 2008; Zielke et al., 2010; Quigley et al., 2012; Zielke et al., 2015 and references within). Normal faults from historic and prehistoric ruptures also can have single event displacements that range up to $11 \mathrm{~m}$ with mean values that exceed $2 \mathrm{~m}$ in many cases (e.g., 1972 Owens Valley, California; 1915 Fairview Peak, Nevada; 1959 Hebgen Lake Montana; after Ramelli et al., 1999; and along normal faults in Central Italy, e.g., Palumbo et al., 2004). From a wide variety of sources for all styles of faulting, to say that maximum average displacement can "reach up to $2 \mathrm{~m}$, or over $2 \mathrm{~m}$ in extraordinary cases" is not consistent with the global records regarding crustal fault ruptures. If the global research and research from South America (e.g., Lettis et al., 1997; Wesnousky, 2008; Roy et al., 2020) shows average displacements of $>2 \mathrm{~m}$, with peak displacements much higher $(>4 \mathrm{~m}$ and up to $7.4 \mathrm{~m}$ along reverse, strike slip, and normal crustal fault ruptures) then these potential ranges of displacements should be outlined as possibilities as well in Chile. This of course has implications for fault rupture hazards as well, and associated design of infrastructure (e.g., pipelines, etc) that cross or are adjacent to active faults. Much of the fault mapping data that currently exists in Chile is not fit 
for this purpose. Regional geological mapping is an excellent base for regional perspectives along active faults, but focused fault-maps based on better field and remote sensing data will allow fault rupture hazards to be better mitigated. New technology like drone photography and light detection and ranging (lidar) derived topography data are two ways that our community can acquire better field data on and around faults that can then be tied with synergistic approaches like seismology and geodetic modeling to develop more a comprehensive understanding of seismogenic potential and fault rupture behaviour.

Point three addresses the division of Chile into 3 tectonic domains, which are not clear from the paper just exactly where these are (a map showing these areas would be of great aid for users), and which do not address the distinct strike-slip setting of Magallanes and potentially of Aysen and Los Lagos in and around the LOFZ (which is perhaps distinct from the Volcanic Arc domain further north), nor of the proposed active extensional domain in Magallanes. The conclusion of their paper states "The continental margin of the Chilean territory is segmented longitudinally into three tectonic domains-External Forearc, Inner Forearc, and Volcanic Arc...". The External forearc (called the Outer Forearc in their Table 3) has normalstrike slip and reverse faults, the Inner Forarc has strike slip and reverse faults, and the Volcanic Arc has strike slip faults. It is important to mention that although the strike slip setting is mentioned in their Table 3 (as a transform fault plate boundary), but not in the abstract nor conclusions of the Santibáñez et al. (2019) paper. For a better understanding of the three divisions proposed by Santibáñez et al. (2019), and for comprehensive coverage of the variability in onshore Chile, I suggest we add a fourth domain (which they allude to in their Table 3), the strikeslip plate boundary found in Magallanes and in and around Tierra Del Fuego and related to the Magallanes Fault System (also referred to as the MagallanesFangano Fault System) recent seismicity data in this area demonstrates that there are shallow events localised along faults in the Magallanes Fault System and also diffuse seismicity that is mostly do to isostatic rebound following the retreat of the Patagonian Ice sheet (Ammirati et al., 2020). To further complicate the story in Magallanes, and southernmost Patagonia, to the North and East of the strike slip plate boundary ( $4^{\text {th }}$ domain: in Chilean Tierra Del Fuego and the continent), I suggest there is what could be considered an extensional tectonic regime (i.e., the "Magellan Rift"; after Diraison et al., 1997), with "ongoing" active normal faulting, rifts and half rifts. Additional mapping and fieldwork by Ghiglione et al. (2012) supports the Diraison et al. (1997) extensional regime. Seismicity in the area may be associated with ongoing tectonic activity within the Magellan rift (e.g., Sabbione et al., 2007; Buffoni et al., 2009). Thus, this extensional setting in and around Tierra Del Fugeo could be considered a $5^{\text {th }}$ domain within Chile. As with the majority of the faults in the other 4 domains, the associated seismic hazard related to these normal faults are currently uncharacterised. To conclude, I propose that at least two other distinct domains should be included in terms of a subdivision of Chile's crustal fault seismic sources zones: 4) the strike slip plate boundary in and around the Magallanes Fault System, and 5) the extensional setting in and around the Straight of Magellan to the east and northeast of the Magallanes Fault System.

Because active neotectonic work based on field is a nascent field in Chile, again the work by Santibáñez et al. (2019) is an excellent step in the right direction for understanding where the faults are located and what the seismic hazard they present, and context. However because of the importance on society due to the hazards that active tectonics present (e.g., fault rupture, strong ground motions and coseismic geohazards like landslides and liquefaction), addressing a few potential points of concern in this review and commentary is important. The limitations that Santibáñez et al. (2019) mention regarding key field parameters, oftentimes have considerable uncertainties, and in many cases parameters such as fault length (i.e., where fault traces are obscured at either end of the rupture tips) are minimums which can underestimate fault area and thus seismic hazard. Nevertheless, understanding what faults and folds are currently accommodating tectonic deformation, i.e., ongoing, and how fast is this happening are key questions globally and in South America and Chile. As outlined by De Pascale et al. (2017), of the $>12,000$ faults segments in the national Chilean fault database, only $\sim 600$ of these are considered "active" or about $5 \%$ of all of the faults are "active" (in stark contrast with California with $71 \%$ and New Zealand with $24 \%$ of mapped faults having evidence of Quaternary activity respectively). What this means or suggests is twofold, A) that perhaps there are less people 
working on the topic in Chile, which means fewer active faults are actually identified as "active" due to a lack of research and data and B) there is much more work for us to do together as a community.

Finally, because development in and around active faults currently have no legal constraints in Chile, i.e., construction is allowed on or across active faults, urgent attention is needed to address this shortcoming. Thus the geoscience and earthquake engineering community should work with the government and legal community to develop plans (perhaps based on the laws and guidelines in Japan, New Zealand, and California) to reduce risk when these active faults (e.g., the San Ramón fault) do rupture in populated areas of Chile. Continued construction along the San Ramón and other active faults in Chile is an accident waiting to happen and if our community does nothing about it, no one will. Thus to conclude, limitations outlined above aside, Santibáñez et al. (2019), have done a solid job to outline the state of our knowledge on active faults in Chile. Although my commentary provides constructive ideas to expand on a few points and uncertainties in their paper, it would be great if in the near term, we as a community can bring together a team of Chilean earthquake geologists, seismologists, and earthquake engineers (even better with input from colleagues across the borders in Argentina, Bolivia, and Peru all areas that have active structures than can cause shaking within Chilean territory) to come together to produce a national probabilistic seismic hazard model of Chile.

\section{References}

Ammirati, J-B.; Flores, M.C.; Ruiz, S. 2020. Seismicity along the Magallanes-Fagnano fault system. Journal of South American Earth Sciences 103: 102799. doi: 10.1016/j.jsames.2020.102799.

Buffoni, C.; Sabbione, N.C.; Connon, G.; Ormaechea, J.L. 2009. Localizacion de hipocentros y determinacion de su magnitud en Tierra del Fuego y zonas aledañas. Geoacta 34: 75-86.

Candia, G.; De Pascale, G.P.; Montalva, G.A.; Ledezma, C. 2017. Geotechnical Aspects of the 2015 Mw 8.3 Illapel Megathrust Earthquake Sequence in Chile. Earthquake Spectra 33 (2): 709. doi: 10.1193/031716EQS043M.

Costa, C.H.; Smalley, R.; Schwartz, D.P.; Stenner, H.D.; Ellis, M.; Ahumada, E.A.; Velasco, M.S. 2006. Paleoseismic Observations of a Onshore Transform
Boundary: The Magallanes-Fagnano Fault, Tierra del Fuego, Argentina. Revista de la Asociacion Geológica Argentina 61 (4): 647-657.

De Pascale, G.P.; Langridge, R.M. 2012. New on-fault evidence for a great earthquake in 1717, central Alpine fault, New Zealand. Geology 40 (9): 791-794.

De Pascale, G.P.; Davies, T.R.; Quigley, M.C. 2014. Lidar reveals uniform Alpine Fault offsets and bimodal plate boundary rupture behavior, New Zealand. Geology 42 (5): 411-414.

De Pascale, G.P.; Araya, J.; Persico, M.; Sandoval, S.; Sepúlveda, S.; Moncada, D. 2017. New school faults and seismic hazard, guilty (i.e., active) until proven innocent (i.e., inactive), PATA DAYS 2017: $8^{\text {th }}$ International Workshop on Paleoseismology, Active Tectonics and Archeoseismology, $13^{\text {th }}-16^{\text {th }}$ November 2017, Blenheim, New Zealand.

Diraison, M.; Cobbold, P.R.; Gapais, D.; Rosello, E.A. 1997. Magellan Strait: Part of a Neogene rift system. Geology 25: 703-706.

Forsyth, D.; Uyeda, S. 1975. On the relative importance of the driving forces of plate motion. Geophysical Journal International 43: 163-200.

Ghiglione, M.C.; Navarrete-Rodríguez, A.T.; GonzálezGuillot, M; Bujalesky, G. 2012. The opening of the Magellan Straight and its geodynamic implications. Terra Nova 00: 1-8.

Grant Ludwig, L. 2013, Treatise on Geophysics, $2^{\text {nd }}$ Ed. Volume 4-Earthquake Seismology: Historical Seismicity Paleoseismology: p. 49.

Gupta, H.; Gahalaut, V. K. 2013. Three Great Tsunamis: Lisbon (1755), Sumatra-Andaman (2004) and Japan (2011): p. 85. doi:10.1007/978-94- 007-6576-4.

Gutenberg, B.; Richter, C.F. 1956. Earthquake magnitude, intensity, energy, and acceleration, Bulletin of the Seismological Society of America 46 (2): 105-145.

Hamling, I.J.; Hreinsdottir, S.; Clark, K.; Elliott, J.; Liang, C.; Fielding, E.; Litchfield, N.; Villamor, P.; Wallace, L.; Wright, T.; D'Anastasio, E.; Bannister, S.; Burbidge, D.; Denys, P.; Gentle, P.; Howarth, J.; Mueller, C.; Palmer, N.; Pearson, C.; Power, W.; Barnes, P.; Barrell, D.; Van Dissen, R.; Langridge, R.; Little, T.; Nicol, A.; Pettinga, J.; Rowland, J.; Stirling, M. 2017. Complex multi-fault rupture during the 2016 Mw 7.8 Kaikoura earthquake, New Zealand. Science 356: 6334.

Jaschek, E.; Sabbione, N.; Sierra, P. 1982. Reubicación de sismos localizados en territorio argentino (19201963). Observatorio Astronómico de la Universidad Nacional de La Plata Serie Geofísica, Tomo XI, No 1. 
Kagan, Y.Y.; Jackson, D.D.; Geller, R.J. 2011. Characteristic earthquake model, 1884-2011: R.I.P. Seismological Research Letters 83 (6): 951-953.

Kagan, Y.Y.; Jackson, D.D. 2013. Tohoku Earthquake: A Surprise?. Bulletin of the Seismological Society of America 103 (2B): 1181-1194.

Kaiser, A.; Holden, C.; Beavan, J.; Beetham, D.; Benites, R.; Celentano, A.; Collett, D.; Cousins, J.; Cubrinovski, M.; Dellow, G.; Denys, P.; Fielding, E.; Fry, B.; Gerstenberger, M.; Langridge, R.; Massey, C.; Motagh, M.; Pondard, N.; McVerry, G.; Ristau, J.; Stirling, M.; Thomas, J.; Uma, S.R.; Zhao, J. 2012. The Mw 6.2 Christchurch earthquake of February 2011: preliminary report. New Zealand Journal of Geology and Geophysics 55 (1): 67-90.

Kanamori, H.; Rivera, L. 2017. An Mw=7.7 slow earthquake in 1960 near the Aysen Fjord region, Chile. Geophysical Journal International 211: 93-106. doi: 10.1093/gji/ggx292.

Kanamori, H.; Rivera, L.; Lambotte, S. 2019. Evidence for a large strike-slip component during the 1960 Chilean earthquake. Geophysical Journal International 218 (1): 1-32.

Lettis, W.; Wells, D.; Baldwin, J. 1997. Empirical observations regarding reverse earthquakes, blind thrust faults, and quaternary deformation: Are blind thrusts truly blind? Bulletin of the Seismological Society of America 87: 1171-1198.

Li, Y-G.; De Pascale, G.P.; Quigley, M.; Gravely, D. 2014. Fault Damage Zones of the M7.1 Darfield and M6.3 Christchurch Earthquake Sources Viewed with FaultZone Trapped Waves. Tectonophysics 618: 79-101.

Lomnitz, C. 1970. Major earthquakes and tsunamis in Chile during the period 1535 to 1955 . Geologische Rundschau 59: 938-960.

Middleton, T.A.; Walker, R.T.; Parsons, B.; Lei, Q.; Zhou, Y.; Ren, Z. 2015. A major, intraplate, normal-faulting earthquake: The 1739 Yinchuan event in northern China. Journal of Geophysical Research Solid Earth 121 (1): 293-320.

Nishenko, S.P. 1991. Circum-Pacific seismic potential 1989-1999. Pure and Applied Geophysics 135: 169-259.

Palumbo, L.; Benedetti, L.; Bourles, D.; Cinque, Al.; Finkel, R. 2004. Slip history of the Magnola fault (Apennines, Central Italy) from $36 \mathrm{Cl}$ surface exposure dating: evidence for strong earthquakes over the Holocene. Earth and Planetary Science Letters 225: 163-176.

Perucca, L.; Alvarado, P.; Saez, M. 2016. Neotectonics and seismicity in southern Patagonia. Geological Journal 51: 545-559.
Pedrera, A.; Galindo-Zaldívar, J.; Ruiz-Constán, A.; Bohoyo, F.; Torres-Carbonell, P.; Ruano, P.; Maestro, A.; González-Castillo, L. 2014. The last major earthquakes along the Magallanes-Fagnano fault system recorded by disturbed trees (Tierra del Fuego, South America). Terra Nova 26: 448-453.

Quigley, M.; Van Dissen, R.; Litchfield, N.; Villamor, P.; Duffy, B.; Barrell, D.; Furlong, K.; Stahl, T.; Bilderback, E.; Noble, D. 2012. Surface rupture during the 2010 Mw 7.1 Darfield (Canterbury) earthquake: implications for fault rupture dynamics and seismic-hazard analysis. Geology 40: 55-58.

Ramelli, A.R.; Bell, J.W.; DePolo, C.M.; Yount, J.C. 1999. Large-Magnitude, Late Holocene Earthquakes on the Genoa Fault, West-Central Nevada and Eastern California. Bulletin of the Seismological Society of America 89 (6): 1458-1472.

Roy, S.; Vassallo, R.; Martinod, J.; Ghiglione, M.C.; Sue, S.; Allemand, P. 2020. Co-seismic deformation and postglacial slip rate along the Magallanes-Fagnano fault, Tierra Del Fuego, Argentina. Terra Nova 31 (1): 1-10.

Ruegg, J.C.; Rudloff, A.; Vigny, C.; Madariaga, R.; de Chabalier, J.B.; Campos, J.; Kausel, E.; Barrientos, S.; Dimitrov, D. 2009. Interseismic strain accumulation measured by GPS in the seismic gap between Constitución and Concepción in Chile. Physics of the Earth and Planetary Interiors 175: 78-85.

Sabbione, N.; Connon, G.; Hormaechea, J.L.; Rosa, M.L. 2007. Estudio de Sismicidad en la Provincia de Tierra del Fuego. Geoacta 32: 41-50.

Sandoval, F.B.; De Pascale, G.P. 2020. Slip rates along the narrow Magallanes Fault System, Tierra del Fuego Region, Patagonia. Scientific Reports 10: 8180.

Santibáñez, I.; Cembrano, J.; García-Pérez, T.; Costa, C.; Yáñez, G.; Marquardt, C.; Arancibia, G.; González, G. 2019. Crustal faults in the Chilean Andes: geological constraints and seismic potential. Andean Geology 46 (1): 32-65. doi: 10.5027/andgeoV46n1-3067.

Satriano, C.; Kiraly, E.; Bernard, P.; Vilotte, J.-P. 2012. The $2012 \mathrm{Mw}$ 8.6 Sumatra earthquake: Evidence of westward sequential seismic ruptures associated to the reactivation of a N-S ocean fabric. Geophysical Research Letters 39: L15302. doi:10.1029/2012GL052387.

Schwartz, D.; Coppersmith, K. 1984. Fault Behavior and Characteristic Earthquakes: Examples from the Wasatch and San Andreas Fault Zones. Journal of Geophysical Research 89 (7): 5681-5698.

Sibson, R.H. 2002. Geology of the crustal earthquake source. In International Handbook of Earthquake 
and Engineering Seismology-Part A (Lee, W.H.K.; Kanamori, H.; Jennings, P.C.; Kisslinger, C.; editors). Academic Press: 455-473. New York.

Stirling, M.W.; McVerry, G.; Gerstenberger, M.; Litchfield, N.; Van Dissen, R.; Berryman, K.; Barnes, P.; Wallace, L.; Villamor, P.; Langridge, R.; Lamarche, G.; Nodder, S.; Reyners, M.; Bradley, B.; Rhoades, D.; Smith, W.; Nicol, A. Pettinga, J.; Clark, K.; Jacobs, K. 2012. National Seismic Hazard Model for New Zealand: 2010 update. Bulletin of the Seismological Society of America. 102: 1514-1542.

Stirling, M.W.; Gerstenberger, M.C.; Goded, T.; Ries, W. 2015. Macroseismic Intensity Assessment for the M6.2 2011 Christchurch Earthquake. GNS Science Consultancy Report 2015/26. February 2015: 51 p.

Vargas, G.; Rebolledo S.; Sepúlveda S.; Lahsen, A.; Thiele R.; Townley B.; Padilla C.; Rauld R.; Herrera M.; Lara, M.; 2013. Submarine earthquake rupture, active faulting and volcanism along the major LiquiñeOfqui Fault Zone and implications for seismic hazard assessment in the Patagonian Andes. Andean Geology 40 (1): 141-171. doi: 10.5027/andgeoV40n1-a07.

Vargas, G.; Klinger, Y.; Rockwell, T.K.; Forman, S.L.; Rebolledo, S.; Baize, S.; Lacassin, R.; Armijo, R. 2014. Probing large intraplate earthquakes at the west flank of the Andes. Geology 42 (12): 1083-1086.

Villalobos, A.; Vargas, G.; Maksymowicz, A.; Ruiz, S.; Lastras, G.; De Pascale, G.P. 2020. Active faulting, submarine surface rupture and seismic migration along the Liquiñe-Ofqui fault system, Patagonian Andes.
Journal of Geophysical Research, Solid Earth 125 (9): e2020JB019946. doi: 10.1029/2020JB019946.

Wesnousky, S.G. 1994. The Gutenburg-Richter or characteristic earthquake distribution, which is it?: Seismological Society of America Bulletin, 84: 1940-1959.

Wesnousky, S.G. 2008. Displacement and Geometrical Characteristics of Earthquake Surface Ruptures: Issues and Implications for Seismic-Hazard Analysis and the Process of Earthquake Rupture. Bulletin of the Seismological Society of America 98 (4): 1609-1632.

Winslow M.A. 1982. The structural evolution of the Magallanes basin and neotectonics in the Southernmost Andes. In Antarctic geosciences, symposium on Antarctic geology and geophysics (Craddrock, C.; editor). University of Wisconsin Press, Madison: 143-154.

Wyss, M. 2020. Return Times of Large Earthquakes Cannot Be Estimated Correctly from Seismicity Rates: 1906 San Francisco and 1717 Alpine Fault Ruptures. Seismological Research Letters 20: 1-7. doi: 10.1785/0220200008.

Zielke, O.; Arrowsmith, J.R.; Grant Ludwig, L.; Akçiz, S.O. 2010. Slip in the 1857 and earlier large earthquakes along the Carrizo Plain, San Andreas Fault. Science 327: 1119-1122. doi: 10.1126/science.1182781.

Zielke, O.; Klinger, Y.; Arrowsmith, J.R. 2015. Fault slip and earthquake recurrence along strike-slip faults-Contributions of high-resolution geomorphic data. Tectonophysics 638: 43-62. doi: 10.1016/j. tecto.2014.11.004.

Manuscript received: November 17, 2019. 